\title{
Media Discourse and the Public Sphere
}

(O Discurso da Mídia e a Esfera Pública)

\author{
Lilie CHOUliaraki \\ (Copenhagen Business School, Institute of Intercultural \\ Communication and Management)
}

\begin{abstract}
RESUMO: Neste artigo, tento pôr em relevo aspectos significativos da função do debate televisivo como esfera pública. Meu pressuposto é que o diálogo público, inclusive o da televisão, envolve fundamentalmente o estabelecimento de um borizonte de sentidos que delimita o que deve ser dito e conbecido, e que estabelece como verdadeiros determinados sentidos e conbecimentos em detrimento de outros. Dizendo de outra forma, bá uma 'política de verdade' em jogo em todo debate mediado que é central na constituição do debate como esfera pública. É precisamente essa política que quero examinar neste artigo. Usando dados empíricos de um programa de debate em horário nobre da televisãa dinamarquesa, que aborda o direito à privacidade das personalidades públicas, analiso as formas de controle interacional e organização dialógica empregadas no debate, focalizando as seguintes questões: Quais são as práticas comunicativas que conferem a legitimidade de debate público ao gênero debate televisivo? Quais são os princípios que regulamentam a comunicação? Quais são os domínios de sentidos construídos por essa regulamentação? E qual é o potencial de deliberação democrática liberado nesses domínios?
\end{abstract}

Palavras-Chave: Mídia; Gênero Debate Televisivo; Análise de Discurso; Sentido Universal/Particular.

ABSTRACT: In this paper, I am attempting to throw into relief significant aspects of the function of television debate as a public sphere. My working assumption is that public dialogue, including its televised versions, involves primarily the establishment of a meaning horizon which delimits what is to be said and known, and which authorises as true certain meanings and knowledges at the expense of others. Put differently, there is a 'politics of truth' at play in every mediated debate which is central in the constitution of the debate as a public sphere. It is precisely this politics that I want to examine in this 
article. Using empirical material from a prime-time debate programme in Danish television, which is concerned with the right to privacy of public personalities, I analyse the forms of interactional control and dialogic organisation employed in the debate, so as to address the following questions: What are the communicative practices which confer upon the television debate genre the legitimacy of public debate? Which are the principles by which communication is regulated? Which are the domains of meaning construed by this regulation? And which is the potential for democratic deliberation released in these domains?

KEY-WORDs: Media; Talk Show Genre; Discourse Analysis; Universal/Particular Meaning.

This piece of research belongs to a tradition in media and cultural studies which treats television as text. The quest is to understand how mediatized experience is produced in meaning. Making sense of media texts primarily involves treating television talk and image as practices of representation situated in specific political and cultural contexts. Earlier interpretative projects involved a preoccupation with the gap between media meanings and the real world and the ideological effects media have on contemporary culture. More recently, post-structuralist theories of meaning have shifted the emphasis away from 'hidden' meanings and towards the articulations of meaning and power in television texts, which themselves produce specific 'reality effects' - rather than reflecting or distorting a reality 'out there'.

My focus in this paper falls on the meaning-power articulations in a specific television genre, the genre of public debate. My assumption is that public debate involves primarily the establishment of a meaning horizon which delimits what is to be said and known, and which authorises as true certain meanings and knowledges at the expense of others. Put differently, there is a politics of truth at play in every mediated debate which is central in the constitution of the debate as a public sphere. It is this 'politics' that I want to examine below.

For an overview of the debate see Hall 1985/1996:11-34; Poster 1990:1-20; Thompson 1990:264-271; Gibbins \& Reimer 1999: 37-53. 


\section{The significance of trivia}

The 'politics of truth' question becomes more prominent when the topic of the debate is not about the sphere of politics proper, say, the Middle East crisis, thus endowing the debate with 'natural' legitimacy, but it is about the 'royal fairy-tale' in Billed Bladet, a local weekly with spicy celebrity stories for domestic consumption. Following Silverstone, I suggest that though media analysis often takes the significant or the 'grand' as the basis of its inquiry, it is actually on the mundane, on the non-political, yet the intensly politicised, which the media operate most significantly: 'The medias filter and frame everyday realities through their singular and multiple representations, producing touchstones, references, for the conduct of everyday life, for the production and maintainance of common sense. And it is here, in what passes for common sense, that we have to ground the study of the media' (Silverstone 1999:6 - emphasis added).

It is precisely this emphasis on how common sense is imperceptibly re-produced in the media, and so re-appears as yet another resource for the conduct of everyday life, that the focus on politics of truth in the debate comes to explore. How is a particular story, devoid of political content in itself, construed as relevant for public debate in television? which meanings on truth and ethics does the story's focus on gossip and trivia entail? to which effects?

\section{Media in the media}

In October 1998, the Danish celebrity magazine Billed Bladet came out with the headline 'Break in the Marriage' - a provocative claim. The claim referred to the marriage of prince Joakim with princess Alexandra; the evidence provided for the claim was two pictures from the Royal Theatre

\footnotetext{
2 Yet, there is another side to this argument: that television debate is not real debate and, therefore, it should not be taken at face value. Indeed, mediatized debate has been strongly challenged as a public sphere genre (for an overview see Livingstone \& Lunt 1994:9-23, but also Habermas 1989/1997, Bourdieu 1998). Moreover, Danish daily press has criticised the programme I analyse here on the grounds that what it promises as debate is a 'circus'- argument sacrificed for the sake of entertainment. I would like to take this argument seriously. In fact, I agree that the debate is not a simulation of the public sphere alone. The self-reflexivity of television I referred to above is also a device for the spectators' play of imagination. Television's fascination with itself and its
} 
of Copenhagen, where the couple appeared to look each their own way. 'There is something terribly wrong in this marriage' commented the text, raquetting the sales of the magazine issue up to over a million and a half. There is nothing less unusual than celebrity magazines coming up with such stories, trivial and fleeting perhaps but spicy enough to satisfy popular voyerism - hence the 'trash' attribute. Yet, in that particular occasion, there was reaction. The royal representative commented on the improper practices of celebrity press ('this has gone too far'), the issue came into national news, whereas the prime time debate shows in Danish television made it that week's topic. On Wednesday $21^{\text {st }}$ and on Thursday $22^{\text {nd }}$ October, an average of 600.000 viewers each time attended heated discussions on the right of the royals to privacy and on the role of celebrity magazines in the public life of the country.

It is the first of these two television debates which is the topic of this article.

What I find interesting in it is the way in which one mass medium, television, reflects upon another, press - or a certain class of it. There is an element of self-reflexivity in television's attempt to deal with journalistic practice itself. Questions of truth and ethics which are raised with respect to the celebrity magazine mirror back the guiding assumptions of mediated debates themselves. This, in turn, throws into relief significant aspects of the function of this television genre as a public sphere ${ }^{3}$. How is the televised debate constituted as public space? What are the communicative practices which confer upon this genre the legitimacy of public debate? Which are the principles by which communication is regulated? Which domains of knowledge are construed as legitimate by this regulation? And which is the potential for democratic deliberation released in these domains?

\footnotetext{
fascination with another medium, celebrity press, address not so much the common sense as the desire of the audience for pleasure. But instead of subscribing to either of the two poles of the argument (debate as either public sphere or circus), I elsewhere take a dual analytical focus on the debate so as to identify the points where its politics of truth articulate with a different kind of politics, the politics of pleasure (Chouliaraki forthcoming).

3 For literature on the function of televised debate as a democratic forum where people deliberate collectively over issues of common interest, see Scannel 1989:135-66; J. B. Thompson 1995:1009; Livingstone \& Lunt 1994:9-35; Wodak R. \& Wetter E. 1997:209-37. For the debate genre in Denmark, see Bruun 1998; 2000:237-60.
} 


\section{The debate as government}

There is, of course, a tight link between the politics of truth and the democratic potential of mediated debate. If the politics of truth authorises the meaning horison in which the debate topic is construed, then it is by assessing the contours of this horison, what it includes and what it excludes as possible knowledge, that we also assess the capacity of the debate to deliberate. That is, the capacity of the debate to subject its topic to rational critique by opening up to scrutinity the interested basis of all relevant knowledge, irrespectively of its status or power ${ }^{4}$.

This, in turn, pressuposes a modest view of democracy, away from the 'grand politics' of the state, the parliament or the party, nontheless equally tied to institutions and to power. It presupposes a 'local' view of democracy as a practice which activates minor and often invisible relations of power so as to act upon the detail of individual conduct, to increase its 'good order', to maximise its freedom. This is a view of democracy which Rose refers to as 'government' (1999:6) and which Hall also applies on the media as 'government by culture' (1997:227-8).

From this point of view, the mediatized debate can be seen as a minor device of government, a mode of ruling through showing how we should think and act under certain norms of civility - it is rule by 'the conduct of conduct', to use Rose's words again (1999:21). Conceptually speaking, the government perspective helps us approach the television debate as a practice of discourse - as a local game of power which involves the mediation of meaning resources. That such resources are indeterminably appropriated by audiences granted, the key issue here is that mediatized debate does suggest which meanings are relevant for public dialogue, and it does enact certain practices of communication as the most appropriate for civic behaviour - it is not and could not have been an 'everything goes' practices. The focus on the politics of truth captures just that aspect of government where competing discourses struggle for hegemony - for authorising their version of truth as 'the' true discourse in the debate.

\footnotetext{
4 See Held 1993, Laclau 1996 for this view of democratic deliberation; Livingstone \& Lunt 1994:35 for a similar norm on mediated debates.

5 For the ground norms of televised public debate and their appropriation by audiences, see Livingstone \& Lunt 1994, chapter 6.
} 


\section{The methodology of Critical Discourse Analysis (CDA)}

The analytical task is then an enquiry 'into the instabilities and flux of meanings and into their transformations, but also into the politics of their fixing' (Silverstone 1999:16). This calls for a Critical Discourse Analytic methodology (Fairclough 1992, 1995; Chouliaraki \& Fairclough 1999). CDA rejects the dominant view of language as primarily a referential system and theorizes language both as practice itself (in its pragmatic or 'performative' dimension) and as representation of practice (in its semantic dimension). Language in this double capacity is discourse - the constitutive power of signification. CDA's claim is, therefore, that forms of knowledge and social identity are produced and transformed within and through discourse in a range of social practices. The methodological assumption of CDA rests on the constructivist view of language and text as a social semiotic (Halliday 1978, 1985). Specifically, this systemic-functional view of language entails the claim that three major types of processes are always at play in semiotic practices: the construction of reality, the enactment of social relations and identities and the construction of text itself (respectively the 'ideational', 'interpersonal' and 'textual' meta-functions of language). The textual metafunction, text-making, is the specifically semiotic facet of the production of social life in social practices and people only engage with reality and with each other semiotically through text-making. Text, therefore, holds a privileged position in the methodological apparatus of $\mathrm{CDA}$, in that it provides a link between concrete meaning-making processes (inlcuding identity-making) and the conditions of possibility (the discursive horizon) which meaning-making draws upon. The CDA methodology treats the linguistic and visual resources of the text as subtle indicators of the struggle over truth, and of the social positions from which truth is spoken. So, the following discourse analysis is a kind of 'magnifying glass' upon the debate, where the object, the word choice, the mode of address are instruments strategically (though not necessarily consciously) mobilised in a play of power ${ }^{6}$.

\footnotetext{
6 For a discussion on the relationship between systemic-functional semiotics and critical discourse analysis see Chouliaraki \& Fairclough 1999, ch.7; for applications of critical discourse analysis specifically on television texts see Fairclough 1995, Madsen \& Andersen 1998, Phillips 1999, Chouliaraki 2000; for a broader discursive perspective on media texts see Hall 1997:208-36.
} 


\section{The debate as an articulation of universal and particular meanings}

But which analytical concepts can best describe the operation whereby a normative discourse is imposed over other meaning possibilities in the debate? This question is best approached via the coupling between the categories of universal and particular (Laclau 1996). The particular refers to here-and-now meaning, to situated and embodied practice, to the concrete event, whereas the universal refers to meaning abstracted from the hereand-now, to a meaning horison which contextualises and evaluates the particular, to a normative ideal. The disjunction between the two is misleading, though. No particular can claim an identity without simultaneously evoking, implictly or explicitly, some horison for its contextualisation - a horison which, at the same time, dissolves the particular by subsuming it in the universal body. By the same token, no universal can be postulated without the simultaneous evokation of a particular identity that 'grounds' it and legitimates it. The two are coemeregent. Caught in this double, any claim to identity is constantly undermined by the very movement which makes it possible: 'the particular exists only in the contradictory movement of asserting at the same time a differential identity and cancelling it through its subsumption in the non-differential medium (the universal)' (Laclau 1996:28). But even if the negotiation of this double is unresolvable at the epistemic level, it is always temporarily settled in specific discursive practices (Winther Jørgensen 2002).

The mediatized debate is an exemplary illustration of this process - it is anchored upon particulars in order to evoke and establish universals.

If 'the universal is no more than a particular that at some moment has become dominant' (Laclau 1996:26), then the analytical task is to track down the process by which this hegemonic operation is accomplished discursively. Indeed, the search for a universal is not a search for a fixed discourse evoked once and for all. The universal is best conceptualised as a principle which controls the signifying process by which, theoretically, any discourse can assign to a particular the function of universal representation. Yet, even though the universal does not have a neccesary content, it would be misleading to assume that it is in constant flux.

Indeed, which discourse acts as universal, at any specific moment, depends upon the power relations and institutional logics of the social practice it is embedded in. 
Though Laclau recognises that, he does not empirically investigate the process by which specific institutional logics stabilise the contigency of discourse towards certain articulations of the universal over others (Bernstein 1990, 1996; Chouliaraki \& Fairclough 1999; Chouliaraki 2001). Analysing the mediatized debate as an institutional practice means, therefore, paying attention to the ways in which the structuring of power within this genre regulates the dialogic flow so as to enable certain discourses only to act as normative horizons.

Following on the above, the issues I address in the analysis are: a. how the particulars are formulated from specific social positions; b. how a dominant discourse on truth is established as universal in the debate, (in the sections 'Truth in objects' and 'The opening sequence. Truth-for-truth'ssake'). The power and interests of the host and his guest are both the condition and a stake in the 'ultimate' fixing of a certain universal. This, in turn, leads me to a commentary on the politics of truth in this part of the debate: c. a discussion on the principle of 'Universal articulations in the debate' and $d$. the potential effects of its politics of truth in the 'Debate as public sphere'.

\section{The debate: 'Fingers off Frederic', Reimer Bo 21.10.98}

On the occasion of Billed Bladet's 'break in the marriage' story, referring to the most popular royal couple in Denmark, the weekly debate programme 'Reimer Bo' came out with the title Fingers off Frederik?.

The reference to Frederik broadens the focus beyond the actual publication on Joakim and Alexandra's marriage, towards the general issue of when the private turns public. Other cases of publicity are also brought to discussion, yet the royalist perspective is clear. The debate is formulated in the specific terms of the royals' right to privacy, thus harmonising with

\footnotetext{
Denmark's national tv channel's (DR) debate programme 'Reimer Bo' was on every Wednesday, from 8 to $8.40 \mathrm{pm}$, for 16 weeks in the period September $2^{\text {nd }}$ to December $2 \mathrm{x}, 1998$. Its host, Reimer Bo Christensen, earlier hosting another successful debate programme ('Rigets Tilstand', March-June 1998), is a well-reputed actuality and debate tv personality, managing an average audience rate of 500.000 people every week. His programme competed with TV2's debate programme, his previous 'Rigets Tilstand', now hosted by Trine Gregorius. 'Rigets Tilstand' run every Thursday at 8 o'clock, managing a slightly higher audience rate.
} 
the concerns expressed by the royal house (though, as I will argue, the stronger the royalist perspective, the less it is discussed). The discussion opens with a confrontation of the main guest of the debate, the chief editor of Billed Bladet, Anders Thisted - it was basically you who started the whole story says Reimer Bo, casting his guest in the role of the protagonist as well as the 'accused'. Anders Thisted sits in a chair facing the host, and both of them are placed at the centre of an amphitheatrical space, surrounded by the audience. It is this opening sequence with Anders Thisted which is the focus of my analysis. Only at the end of the confrontation, the host leaves his chair and moves among the audience to ask further questions.

Continuity and coherence throughout the host's interactions with various guests is established through five publication cases which, the one after the other, structure separate but interrelated sequences of exchange. Each sequence takes up the debate topic by reference to a specific celebrity magazine story ${ }^{8}$.

Thus, issues on the truth and ethics of press journalism, universal meanings which underpin the topic, emerge in the course of local talk on these specific stories, these particulars. And the point about the truth claims and ethical values of journalism is that their content is not settled but it is precisely the stake of the debate. Truth and ethics are, rather, empty signifiers in this discursive practice, to use Laclau \& Mouffe's words. Dispersed and disconnected as they are in the flow of language, they do not form a readily available and coherent principle of explaining the particular - they rather 'await' fixity by their multiple and differential references to this particular.

The articulation of the particular, and the universalising and particularising of normative horisons of meaning are the main moves that constitute the discursive field of the debate. My analysis below focuses on two aspects of these universal/particular moves: first, the use of celebrity magazines as objects in the programme (Truth in objects) and second, the management of the argumentative dynamics in Reimer Bo's confrontation with Ander Thisted (Truth in language). In order to show how the host's

\footnotetext{
8 Apart from the main story in Billed Bladet, the programme also introduces the following celebrity stories: Her og Nu: speculative story on Alexandra's pregnancy; Ekstra Bladet: a story on Frederik's night-life in Paris; Kig Ind: famous comedian accused as a car thief; Alt for Damerne: a female politician takes part in car advertising and models for a fashion shoot in lifestyle women's magazine.
} 
power turns into interactional control, I pick out and condense Reimer Bo's own questions to Anders Thisted as well as the ways in which Reimer Bo treats his interlocutor's responses - respectively, the sections 'Truth made universal' and 'Truth kept particular' below. But first, 'Truth in objects'.

\section{Truth in objects}

Celebrity magazines are not only talked about in the programme. They are also shown, touched, read in the programme. Their materiality as tangible objects is drawn into the debate at strategic points. Every time a particular story is introduced, Reimer Bo holds the relevant magazine issue in his hands and, whilst the camera zooms onto it, he reads from it or describes the pictures in it.

As mentioned, the magazines function as a cohesive device in that they structure the five sequential units of the debate. They embody the particular, the here-and-now meanings of celebrity journalism, upon which a concrete discussion on the how and why of each story rests. As such, the magazines function as points of reference with respect to which more abstract meanings are articulated - the universals on the truth and ethics of this journalism. Let me sum up the specific contribution the magazines as objects make to the establishment of universal meanings.

First, the presence of magazines keep journalists particular, too. All journalists in the programme are introduced through their relationship to a specific celebrity story, they are held responsible for it and are expected to defend it. As a consequence, their space of argumentation is considerably narrowed down - the move from the particular story to a universal argument on, say, journalistic ethics is seriously restricted for them (see how a Her $\varepsilon N u$ journalist was called to order. Journalist:...but it's quite impressive that you had to go so far back to find a spectacular front page, Reimer Bo: you should respond to what you have been asked - laughter).

Second, the magazines function as factual evidence. All Reimer Bo's questions to these journalists begin (and usually end) with a claim to truth, a cross-check between the magazine's story and the real events. For example, this is how Reimer Bo ridicules the claim of a 1997 Her og $N u$ issue that Alexandra was pregnant - a claim predating Alexandra's pregnancy by 
two years. He flags the magazine issue, gives time details (10 April 1997) and a direct quote (Alexandra pregnant), and whilst the camera zooms on the magazine's cover, he asks: how's the child? - a sharp sarcasm. The presence of the object as evidence of Reimer Bo's truth claims works to produce authenticity and to oblige audience to conviction. Compare the advantages of this confrontation based on the force of the magazine's photo and layout vs a hypothetical confrontation based on, say, Reimer Bo's own recollections of the publication - 'I remember last year you came out with a solo story on your front page where ...'.

The presence of the celebrity magazine as object in this programme can be seen as one technique through which a truth universal is implicitly established - a technique of 'globalising' meanings (Latour 1996). Globalising refers precisely to the effect of fixity conferred upon meanings by the physical materiality of objects. The immediacy of the pictures, the detail of the layout, the specificity of time details, the association with concrete people physically present in the programme (the journalists) all combine together to endow celebrity journalism with facticity and authenticity. Each time a story is challenged, the magazine issue in question is flagged as evidence of fraud.

In this way, the presence of the magazine becomes instrumental in a specific truth operation: the recovery of facts. In a first move, the magazine's truth claim is measured against reality, a reality evoked either by Reimer Bo's reference to external events or by insiders' own accounts. In a second move, the magazine's truth claim is proclaimed invalid precisely because it has failed to relate to the world of facts. In this operation, the assessment of celebrity journalism, the 'accused' in this programme, seems to take place within a discourse of legal positivism: questions of the multiple values (and therefore of competing truths) involved in the mediated representations of public personalities are kept separate from questions of fact. The latter are recoverable as such (Goodrich 1994:328). Though this truth operation is part of a broader mechanism for the establishment of a truth regime in the debate, it is the only one which systematically reappears throughout the programme, thus setting the ground norm for the assessement of truth.

The politics of truth enacted by the celebrity magazine as object can be summed up in 'globalise the particular to universalise'. This implies that 
the insertion of the celebrity magazine as an object in the debate works to keep one semiotic form, the visual, constantly in the service of one universal. Irrespectively of the linguistic struggles to impose different truth interests on this class of press, the object itself speaks one truth: celebrity press is unequivocally untruthful and untrustworthy. Because this modality is not centrally perceived to create meaning (objects are usually taken as 'givens' rather than as semiotic resources), its effect in fixing meaning becomes even stronger.

As a consequence, the possibility of discussing celebrity press as something else than just 'the village's fool' spreading rumours, as Reimer Bo put it, is considerably narrowed down. Let us now move to the linguistic representations of truth in the opening sequence of the programme.

\section{Truth in language}

* what are you grounding this on $P$ break in the marriage

* have these six journalists written all they knew I see two pictures and I see a text where they somehow speculate that the marriage is in trouble (2/7-9)

* now when you have (...) when you now have a story like this which you think is really good and you have six really really smart journalists did you ring to the interested parties before you published this story

Truth made universal: These are Reimer Bo's first three questions. Each refers to a particular, to a specific operation of the Billet Bladet text, in order 'dig out' the premise on which each operation is grounded. But, although each question evokes a certain particular, altogether they establish a chain of equivalential demands (Laclau 1996) - a field of meanings within which these particulars are placed. Thus, each question contributes to building up a discursive horison in which the truth and validity of journalistic practice are construed and understood. It is within this regime of truth that a certain epistemology of representation is made universal in the debate. Specifically, all three questions address the claims to truth in BB's text: evidence status (what are you grounding this on); evidence adequacy (I see two pictures and I see a text); evidence validity (did you ring to the interested parties before you published the story). 
The first question undermines the very status of evidence provided by the magazine to support the claim 'break in the marriage' - that is two photographs of the royal couple at the Royal Theatre, each looking their own way. The bvad in Reimer Bo's initial question what are you grounding this on $P$ break in the marriage? begs for a specification of the source of information itself. In so doing, the question implies that the photographic material of the reportage cannot be taken as a given piece of evidence. Reimer Bo's next question casts double doubt upon the magazine's evidence adequacy. First, it casts doubt upon the journalists as legitimate sources of information, suggesting that there may be more to reality than what they write about: have these six journalists written all they knew. Second, it casts doubt on the photographic material of the reportage, suggesting that it is poor evidence to reality I see two pictures and I see a text where they somehow speculate that the marriage is in trouble. In insisting on what he sees (I see, twice, a perception rather than a cognitive process - compare to 'understand' or 'get to know'), Reimer Bo destabilises the automatic interpretative link readers usually establish between picture and text in order to make sense of a story - what Barthes calls the 'anchoring' of the picture onto text. Separating the two (two pictures... a text), leaves the coherence of the story suspended. In Reimer Bo's talk, the interpretative link (break in the marriage) is thus attributed solely to the story writers themselves (where you somehow speculate - compare to a potential use of a perception process such as 'show' or 'demonstrate'). In both cases, the doubt towards journalists and the doubt towards photographic evidence, it is implied that there is a dislocation between the truth claimed in the story and the truth outside the story. On these grounds, Reimer Bo discredits Billed Bladet's credibility. But he does not abandon truth claims as such. For Reimer Bo, truth exists outside its narrativisation and it is possible to recover. His third question, on validation procedures, suggests such a possible locus for truth: the testimony of the 'protagonists' of the story, in this case the royal environment (did you ring to the interested parties before you published the story).

The universal can be described as a move from the particular, Reimer Bo's questions and other relevant references to the 'knas i ægteskabet' text, to the formulation of a normative discourse on truth that informs journalistic practice. 
This universal posits an external reality which is possible to recover accurately. Truth is verifiable-falsifiable by a procedure of matching locution, the text, to this reality. Such evidence is provided through insiders' knowledge, the testimony of those 'within'. The journalism of this universal establishes facts: a story has to be based on hard data rather than speculative evaluations - Billed Bladet's photographs are relativised as contingent and partial. A story also has to be cross-checked through contact with the parties involved - failing to do so, leaves the truthfullness of the text suspended.

What appears as a universal in this text is a specific discourse on truth, what I earlier referred to as a discourse of legal positivism, which frames and evaluates the particulars of the Billed Bladet story. This discourse is based upon a radical split between fact and evaluation - it selectively elevates some elements as crucial in the pronouncement of truth (facts), whereas others are construed as subjective speculation (evaluations). The ethical 'moment' of the discourse is precisely the moment of the recovery of truth, of factualising reality. It does so, via the positivist operation of privileging one locus of truth over others: insiders have direct acces to reality, they know best. However, in positing an external reality, the discourse obscures the ways in which language always-already participates in defining what a fact is before it 'recovers' it. The regime of truth which makes this epistemological operation possible simultaneously denies its own partiality, its own politics of representation. On the one hand, Billed Bladet's 'fact' of a conflict in the royal couple - itself established by force of the photographic image (and the powerful visual 'I-see-therefore-Ibelieve' epistemology) - is relativised as 'evaluation'. On the other, insiders' accounts are elevated to privileged validity criteria for truth, though one might wonder if such participants do not inevitably provide interested and thus partial account of events.

what are you grounding this on $P$ break in the marriage. To this question, Anders Thisted responds as follows: well we're grounding it of course on the research we did $P$ I bave six journalists who work on the royal family domain and it's clear that they should report on what they experience you can't just say $T$ send six journalists out in the field and tell them well you must come back and write about everything that's good and glamorous but if you see some who are in trouble some who can't make it please tell your colleagues in the canteen but the readers (Reimer Bo: have they written) they can just be fooled... (Reimer Bo: have these six journalists written all they knew) 
Truth kept particular: The direct response to Reimer Bo comes in the first two lines of Anders Thisted's turn: well we're grounding it of course on the research we did P I have six journalists who work on the royal family domain... Notice here the choice of the word research that denotes thorough investigation, the choice of a numerative (six) to specify the precise number of journalists, and the choice of expressions like field work (out in the field) and subject-matter area (domain) to specify the procedure and subjects under research. The field of meanings concentrated in this brief sentence construes truth as a product of specialised, quasi-scientific work. Research, fieldwork, subject-matter area, professional expertise, collective enterprise all contribute to injecting celebrity journalism with authority and credibility.

Further, the discourse categorically (it's clear) construes truth as the journalists' own experience (what they experience) of an external reality, 'in the field' (ud i marken) - compare this to Reimer Bo's locus of truth which is 'protagonists' or insiders rather than journalists themselves. Reality is construed as an object of direct perception - vision (but if you see; and again in the claim that readers can be fooled). And it is disconnected from the process of representation - journalistic writing. This latter belongs to a distinct sphere - the office or 'home' (notice the komme bjem expression twice in the quote). It is the process of representation 'back home' that is subject to manipulation. How the journalistic 'gaze' is produced as public text is a question of ethics.

Indeed, by use of deontic modality (you can't just say...), Anders Thisted spells out an ethics that guides the representation of the real world. Transparency. The journalists mediate between the real and the readers under the obligation (they should report on) that they make visible everything they see: not only the positive (everything that's good ...) but also the negative sides of reality (some who are in trouble ...) - the metaphor for the latter is the 'backside' as Anders Thisted puts it later on. Like Reimer Bo, Anders Thisted's discourse on truth posits an objective reality existing independently of particular interests - specifically, here, the interests of the royal family. Unlike Reimer Bo, the 'moment' of ethics in this discourse, lies in the manner of mediation - not as a recovery of facts, but as an extension of the field of public visibility. The committment is to the readers, the public - that some topics may be kept 'between us' (tell your colleagues in the canteen) constitutes deception: the readers can just be fooled. 
We saw that Anders Thisted's direct response to what are you grounding it on was the construal of Billed Bladet's journalism as collective research of professionals in their expert area, coupled by a universal on journalistic truth as a matter of transparency. In the argumentative dynamics of the interaction, this elaborate response is left suspened. The host cuts Anders Thisted off to come back on track: have these six journalists written all they knew I see two pictures and I see a text where they somehow speculate that the marriage is in trouble. Anders Thisted is pushed to respond to the specifics of the story's validity. His discourse is kept particular. His answer, though, 'deviates' towards another universal:

Well we say yes it's obvious there is break in the marriage because $\boldsymbol{P}$ it's not it's just not easy to be P let me tell you it's just not easy for a foreigner to move to Denmark it sounds so great that you can move from one culture to the other (...) but it's not that easy to manage in Denmark we are not that tolerant and $P$ that easy to socialise with (...) and it's clear that for Alexandra the conditions are more or less the same as for other people $P$ and like I said if you want to tell the positive sides you're also obliged to engage with the 'backside' of it (Reimer Bo: when you now have) it's no publicity (2/13-24).

Here, Anders Thisted draws on a discourse of cultural mismatch, which foregrounds the difficulties of adaptation foreigners face in the country: it's just not easy for a foreigner to move to Denmark; it's not that easy to manage in Denmark. This is a popular discourse on immigrant relations in Denmark. In this environment, the discourse acts as a meaning horizon contextualising a certain class of particulars, intercultural marriages - including the supposed conflict in the royal couple (as Alexandra comes from Hong Kong). Notice how the discourse lifts the royal member out of her particularity and alligns her with foreigners as a universal class: foreigner; for Alexandra the conditions are more or less the same as for other people.

What this discourse universalises is one explanatory version which could lend legitimacy to Billed Bladet's own truth claim - cultural mismatch leads to marital conflicts. It is activated at this point to provide that interpretative link between the photographic material and the 'knas $i$ ægteskabet' text which Reimer Bo had skillfully rendered arbitrary above: I see two pictures and I see a text. But once such a dislocation has taken place and Billed Bladet's own interpretation loses its 'natural' force, any universal that 'comes to rescue' equally runs the risk of exposing its own arbitrariness. Any explanation would do as well as that of the cultural mismatch - perhaps even better. 
It is in order to strengthen his argumentative position that Anders Thisted's seeks further support from his epistemological universal already introduced above: like I said if you want to tell the positive sides you're also obliged to engage with the 'backside' of it (Reimer Bo: when you now have) it's no publicity. If the discourse of cultural mismatch cannot validate the story, then the discourse on truth as transparency would. Here, modality construes journalistic practice as a matter of volition ( $\mathrm{vil}$ ), a wish to recount a positive reality, and as obligation (you're also obliged to), a duty to attend to its 'backside' - two distinct modes of attachment to the journalistic task. But, at the same time, these modes of attachment are structured in a conditional clause, if you, which subordinates wish to obligation and construes the journalistic ethic again as committment to transparency (if you want plus, then you are also obliged to minus). Notice here the contrast of this ethics with advertising, a practice which operates exclusively on the wish to visibilise the positive without a conditional obligation: it's no publicity. The effect is that Anders Thisted takes a distance from an ethic that would subordinate transparency to vested interests, here advertising for the royals.

This univeralising attempt remains again suspended. As before, Reimer Bo interrupts Anders Thisted's talk to ask another question:

...Anders Thisted: you're also obliged to engage with the 'backside' of it Reimer Bo: now when you bave - Anders Thisted: this is no publicity... Reimer Bo:

now when you have (...) when you now have a story like this which you think is really good and you have six really really smart journalists did you then ring to the interested parties before you published this story

Reimer Bo's intervention particularises. Present tense, now when you have (...) when you now have, the use of now twice, as well as the and-links connecting all processes, construe story-writing as a step-by-step process in a here-and-now context. Once established as the particular relevant for discussion, story-writing is then approached from the temporal perspective of the debate - there is a shift to past tense in did you then ring (...).

The qualifiers of amount, seks, and manner, six really really smart journalists, echo Anders Thisted's earlier argument on the professionalism of Billet Bladet's research (notice the repetition of the numerical, six, and 
the double use of qualifier of manner, really). This intertextual weaving of Anders Thisted's discourse in Reimer Bo's current narrative has a certain effect: irony. This is based on the contrast between the journalists' deliberately emphasised competence and their failure to follow the professional norm (cross-checking information). A failure anticipated in Reimer Bo's question and confirmed in Anders Thisted's negative response: no we just can't ... we just can't come to talk with the interested parties but it's clear that we talk with the royal milieu we do that to a great extend.

Notice, again, Anders Thisted's move away from the particular and towards a universal. First, his negative response is qualified by a present tense modal (can't) which de-temporalises possibility and construes Reimer Bo's suggestion as impossible not because of specific circumstances, but because of general conditions: journalists do not have direct access to the royal family, the 'protagonists' of the story. This implication is rather off the point (everybody knows that journalists don't just ring up the prince), but it offers Anders Thisted the rhetorical advantage of moderating his negative response with some degree of plausibility. His second responsive move, addressing (more to the point) contact with the royal milieu, still continues to steer away from the particular case: but it's clear that we talk with the royal milieu we do that to a great extend.

Present tense, we talk, and a frequency adverb, to a great extend, again project a general, de-temporalised state of affairs rather a circumstance. This insistence upon the general invites yet another question from Reimer Bo's - temporalised, did you ring, and specific, this story.

The host's 'pushing-in-the-corner' strategy does not give Anders Thisted enough space to move to another universal without the cost of appearing to suspiciously evade the question. His next and final turn is a direct answer to Reimer Bo's question did you ring to the interested parties.... He manages, however, to evade the question's topical focus: $h m$ yes $P I$ can't just sit here and tell you which sources em all journalists have and who they contacted and why and how I don't know but... First, Anders Thisted substitutes the royal milieu with sources, turning a specific into a general category. Then, he lines up 'sources' in a long chain of multiple topical specifications (all hv-constructions demanding new information): which sources em all journalists have and who they contacted and why and how. Parataxis (the use of andlinks) has two interrelated effects. On the one hand, not only is the who- 
specification kept abstract (who), but it is further diffused and de-focused among others. On the other hand, the cumulative effect of parataxis is that of an information overload. Reimer Bo 'asks-for-too-much' and this makes it possible for Anders Thisted's to claim ignorance, I don't know, and to avoid responding again.

Men, an adversative conjunction, allows Anders Thisted to move quickly away from this particular and re-focus upon the meaning horizon in which his story is most convincingly legitimated. The rest of his talk can be seen as consisting of four related intertexts, which cumulatively build up Anders Thisted's preferred universal: the quasi-scientific discourse of journalistic professionalism (but it's smart people we're talking about) and the discourse on truth as transparency with its concommitant obligation to attend to the 'naturally right' (deontic modality: cannot; is obliged to engage with what happens to be right). In the final turn, the 'naturally right' is established by reference to external reality (and we are in contact with reality), which enables Anders Thisted to re-assert the validity of his story (and it's correct what stands in the story) - notice that the use of the semi-scientific correct suggests that the truth of the story is accurately recoverable.

With the exception of this last clause, Anders Thisted's talk operates exclusively on universal meanings - discourses on professional competence and truth, in which the particular, the story, is contextualised. These meanings are linked together paratactically (with and-links) rather than hypotactically (with because of; despite of; as a result of etc links). In this way, Anders Thisted's text both avoids argumentative depth, in that there are no references to reasons or effects, and obstracts linkages to real-timeand-place accounts. His text excludes the particular.

Reimer Bo leaves the dialogue with Anders Thisted here and turns to Søren Haslund Christiansen, the royal representative. The shift is timely. An insider is drawn into the debate precisely at the moment when his 'voice' is shown to have been excluded from Billed Bladet. The move sets up a contrast between celebrity journalism and the $\mathrm{tv}$ journalism of Reimer Bo. Enacting the principle of involving interested parties adds to the ethical aura of the latter, whilst it further exposes the ethical 'nakedness' of the former. At the same time, from an argumentative point of view, Reimer Bo appears to have rest his case. 
Concerning the truth claims of the case under debate, his interlocutor has failed. Anders Thisted consistently avoided to give precise responses to the host's persistent questioning - rather than defending his argument with concrete documentation, he is talking 'thin air'.

\section{The politics of truth in the debate}

The opening sequence can be summed up in terms of two different positions in the field of meanings available in the debate. Each offers a distinct norm of truth. Though both share an objectivist epsitemology in appealing to external reality, they differ in the procedures of validating truth and, thereby, on the ethics of representation each validity procedure implies. Reimer Bo posits a discourse on truth as the establishment of facts and its ethics 'oblige' the journalistic text to maintain a tight match between fact and locution. Anders Thisted posits a discourse on truth as transparency of representation and its ethics 'obliges' the text to encompass an ever-broadened field of visibility. Whereas the first makes a commitment to truth-as-an-end-in-itself, the latter makes a commitment to the social body, the readers. Of the two, it is the first discourse, which acquires the status of the universal - the natural meaning horizon which contextualises and evaluates other discourses. As mentioned, it is the host, Reimer Bo, who is the carrier of this discourse. This is by virtue of his structural positioning in the practice of the debate and, specifically, by virtue of his control over who participates, as well as over turn-taking and topic-shifts - including his right to interrupt, reformulate and recoup.

It appears that the organising principle in debating truth is 'keep particular'.

We saw that the discursive practice begins and ends with specific references to one publication of Billed Bladet. Its status, adequacy and validity is systematically tied down to the language, the pictures and the step-by-step actions of the journalists. These references to the particular accumulate a set of equivalential meanings on what is evidence, on what is adequacy of evidence, on what is validation of truth and how it is accomplished, which, dispersed as they are, constitute a powerful discursive field. We could claim that the discourse on truth as the establishment of facts is construed in the course of the practice of questioning, its linguistic 
detail and interactional set up. This means that the universal is activated as a mode of control, a mode best described as 'individuating' a rationality: singling out the epistemological properties of the publication and getting down to its nitty-gritty details so as to disprove it (Rose 1999:275). This mode of control is strategic in constituting the debate as a public sphere: the rational, detached examination of a class of social practices, celebrity press, in a public forum. Indeed, it is precisely the capacity of a collective space to assume an aperspectival objectivity, a perspective from nowhere, which confers on this space the political legitimacy of a public sphere - a legitimacy also conferred to the host as impartial spectator committed to the truth and only to that (Boltanski 1999:32; see also Bourdieu 1992)9.

By the same token, the mode of control of the practice affords only one position for Anders Thisted, that of keeping particular too. This proved to be effective for Reimer Bo in that he managed to catch Anders Thisted in a double bind.

On the one hand, had he kept to the particular, Anders Thisted would have run the risk of getting nailed down. Indeed, he did not appear in position to give concrete details of the story. Concerning the status of his evidence, the sociological discourse of cultural mismatch sounded like a rather long shot as a legitimate explanation of two pictures of the royal couple not looking at each other. Concerning the validation of his evidence, that is contact with the parties involved, his evasive responses discredited his appeal to truth.

On the other hand, Anders Thisted's preferred defense strategy, to make available a competing discourse on truth, also proved to be ineffective. Unlike Reimer Bo's implicit universal, this counter-universal took the form of explicit expositions which connected to the particular, the story, either very loosely or not at all. Such contributions were construed as irrelevant to the pragmatics of the interaction. They made claims to appropriacy, the social norms and values that guide journalistic practice, rather than addressing the claims to truth, the validity criteria of the specific publication, as Reimer Bo had it. As a consequence, they were ignored. Anders Thisted's

\footnotetext{
9 The constitution of a public sphere and a definition of political legitimacy based on a conception of objectivity that emphasises the possibility of an observation without any particular perspective are strictly interdependent (Boltanski 1999:24).
} 
inistence on the ethics of journalism as transparency was, thus, deprived of the legitimacy to act as a contextualising frame for the particular - it was denied the capacity to become universal.

More specifically, now, the politics of truth in this sequence of the debate can be summed up as 'keep particular to universalise'. The power to universalise truth, in other words, does not lie in being able to explicitly articulate a set of meanings, to make the discourse visible. On the contrary, the power to universalise truth lies in embedding the discourse as a pressuposition in a specific procedure of questioning. Indeed, the more Anders Thisted keeps producing universal statements (statements disconnected from the specifics of the case) the more his responses are controlled to remain particular. The more Reimer Bo's questions 'hammer upon' the particular, the more universal validity they acquire.

It is precisely its status as a non-discourse that enables Reimer Bo's truth to work as a material technique of government - a technique for regulating the debate as a public sphere so that certain things only can be constituted as truthful and legitimate, as universal (Rose 1999:36-7).

Universalising is indeed inevitable in public debate. How else can a group of people deliberate unless on a ground of common understandings? But the question is which interest is kept suppressed by this specific operation of hegemonising one discourse on truth over another? The relentless questioning in this sequence construed the Billed Bladet story as fiction rather than fact, and so it implictly privileged a certain truth: the supposed conflict in the royal couple did not take place. This is, of course, a truth which upholds the royal family's positive image: royals don't fight at least in public - an interest already evident in the title and choice of story. Prioritising this truth at this early point in the debate does quickly away with the doubt concerning the incident itself and is 'free' to move on to a debate proper of the 'real' issue - privacy and the ethics of celebrity press.

In this sense, the universalising of a legal positivist discourse on truth carries the cost of a displacement: in the course of debating, the royalist interest is construed under the guise of aperspectival objectivity, and therefore as beyond discussion. Thus, the restoration of royal family's integrity becomes an implicit undertext upon which discourses on truth and ethics of journalism are convincingly articulated. 


\section{The debate as public sphere}

In this article, I followed the process by which a legal positivist discourse on truth acquired universal validity in a television debate on celebrity press and public personalities' right to privacy. I exemplified two aspects of this universalising process. First, the insertion of the celebrity magazine as an object in a procedure of recovering the truth. Second, the linguistic procedure of questioning the truth claims of a specific celebrity press publication. The first, the use of objects, universalises by 'globalising' meaning, that is by fixing the meaning of celebrity press as untruthful journalism and by evoking this meaning throughout the programme. The second, the procedure of questioning, universalises by keeping the interaction particular, that is by focusing exclusively on the details of the publication - evidence status, adequacy and validity.

Via this double truth operation, the debate programme is construed in terms of an aperspectival objectivity - a perspective from nowhere which is after truth-for-truth's-sake. Aperspectival objectivity manages to confer upon the debate the legitimacy of the public sphere as the collective endavour of an unbiased search for truth. At the same time, it manages to render normative the royalist interest which underpins this search for truth and which informs the ethical and aesthetic norms of the debate overall.

In the beginning of this article, I postulated that the democratic function of the mediated debate is to be assessed by the way it construes its dialogic space - by universalising, that is by rendering normative, the specific discourses on truth and ethics it does and by particularising, that is by denying authority to other discourses that do not 'fit' its regulative logic. This debate is subject to the critique of failing to fullfill its democratic function insofar as it renders normative, and therefore avoids discussing, a certain interest - the royalist interest. The point is not that the royal family is not victimised by a mercilessly avid celebrity press. It is. The 'gaze' of celebrity press constitutes probably one of the most powerful fields of discipline for the conduct, both public and private, of royal members and that should be held in check. However, the position of the royal family in the institutional landscape of the country is complex. For one thing, the rare privileges of the royal family do come with the obligation of heightened visibility vis a vis"ordinary citizens. Furthermore, the royal family's own performance is itself situated at a cross-section between the private and 
the public, with often fuzzy lines between the two. The royal theatre appearance is only a small example of precisely this fuzziness. Do the royals attend a public event as private individuals or do they do so as institutional representatives of the nation?

Such issues do raise the question of individual sovereingty for the members of the royal family. Where does their privacy stop and the public begins?

But who decides and under which circumstances where the borders of individual sovereingty lie is not an easy matter. It is perhaps the most fundamental controversy in contemporary democracies (Held 1993:3034). In this mediated debate what is itself a stake in the discussion was construed as beyond discussion - it was already precluded in its discourse. Ironically, perhaps, these are some of the issues Anders Thisted tried to put on the agenda.

Two consequences follow from this premature closure. First, the right to privacy, essentially the issue of the borders of individual sovereingty, is cast throughout the debate as an issue of truth vs lies - the right to privacy is activated when celebrity press' lies and rumours begin. This is a circular argument, insofar as the question of truth is itself open to multiple interpretations. What is truth is embedded in different logics of representation, as the Reimer Bo-Anders Thisted exchange made clear. There is an inherent relativism in this argument, which can only be anchored on a normative principle when the competing interests of both sides are put explicitly on the agenda and discussed as such. Selectively suppressing one of them leads to argumentative circularity - a reproduction of common sense, as Silverstone has put it. How to decide when the right to privacy clashes with the right to inform is primarily a question of ethics. Interestingly, throughout the debate, every time Anders Thisted put forward an ethical claim (of the 'readers-need-to-know' type), he was confronted with a truth claim.

But how did ethics figure in this programme?

This brings me to the second consequence of aperspectival objectivity in the debate. Ethics, as I mentioned, does not figure as a practice of juxtaposing rationalities and their interests. It rather takes the form of a code of conduct, a model of acting for the good citizen. Truth is implicated in this 
code in two ways. First, there is a prescription for acting truthfully which is directed to celebrity press, and specifically to Billed Bladet. The magazine should soon come out with a falsification and an apology for its improper publication - this is an explicit formulation of the code. Second, there is a systematic undermining of the celebrity press as journalism proper, which turns its untruthfullness into a marker of (low) ethical and aesthetic status. We should keep a distance to celebrity magasines because they are 'the village's fool', telling absurd lies and spreading rumours. This is an implicit formulation of the code which addresses the television audience and attempts to moralise its consumption practices - thus again reproducing a common sensical judgement of taste, the low aesthetics of trash media.

\section{Conclusion}

In this article, I spoke of the way in which a television debate enacts public dialogue: how it mobilises a certain politics of truth to confer legitimacy upon itself by thematising a non-political issue in a celebrity magasine. The public sphere function of this debate can be summed up as a governmental act of etho-politics. It is an attempt to regulate self-conduct by imposing certain norms of civility and ethics (as well as aesthetics) under the guise of objective rationality. Drawing on Rose (1999:192-3), this is a specification of etho-politics gravitating towards the 'pole of morality', a prescriptive code of conduct.

One question for the critical analysis of television debate is, therefore, that of seeking an alternative set of norms for the government of conduct, which moves away from prescriptive morality. That would involve a debate practice which politics of truth 'validates diverse ethical criteria' 'minimizes codification and maximizes debate' - what Rose (ibid) calls the 'pole of ethics' rather than morality. The contrastive analysis of 'Reimer Bo' with 'Rigets Tilstand' points to such alternatives, without suggesting that the latter is the most desirable genre.

Another issue for the critical analysis of television debate would be to take seriously what, at face value, appears to be trivial affairs. Just like celebrity gossip is not outside the domain of the political (and indeed, as 'Reimer Bo' showed, it is a deeply politicised matter), so debate shows should not be rejected as argument sacrificed for entertainment, pure 
spectacle. Rather the task is to complement the study of the debate's politics of truth, what Silverstone calls the 'rhetoric' of television, with a study of its politics of pleasure, what he names the 'erotic' aspect of television. This erotic element, how television grants its audience the pleasure of watching, is not a trivial matter - it is a constitutive part of it. The significance of trivia seems to me to be more significant than we take them to be. They may help us understand better what is happening to democratic debate when television claims to seek the truth. They may also help us re-think how meaning can be re-articulated in the same media under a different politics of truth with hopefully different effects.

E-mail: liliec@hum.ku.dk

\section{BIBLIOGRAPHY}

Bernstein, B. 1990. Class Codes E Control Vol. IV. The Structuring of Pedagogic Discourse. London: Routledge. . 1996. Pedagogy, Symbolic Control E Identity. London: Taylor \& Francis.

Boltanski, L. 1999. Distant Suffering. Politics, Morality \& the Media. Cambridge: Cambridge UP.

Bourdieu, P. 1992. Language and Symbolic Power. Cambridge: Polity. . 1998. On Television. New York: New Press.

BRUUn, H. 1998. Talkshowet som tv-genre. In: Kvan, 50. . 2000. Eleva2ren - TV2 og Talkshowet. In: Bruun H., Frandsen K. \& Søndergaard H. (eds) TV2 på Skcermen. Analyser af TV2's programvirksombed. Samfundslitteratur, København.

Chouliaraki, L. \& Fairclough N. 1999. Discourse in Late Modernity. Edinburgh: Edinburgh UP.

Chouliaraki, L. 2000. Political Discourse in the News. Democratising Responsibility or Aestheticizing Politics. In: Discourse E Society, 11.3. . 2001. Pædagogikens Sociale Logik. In: Chouliaraki L. \& Bayer

M. (eds) B. Bernstein. Pcedagogik, Diskurs, Magt. Copenhagen: Akademisk Forlag. . (forthcoming) Discourse $E$ Culture. The Significance of Trivia. London: Sage.

Fairclough, N. 1992. Discourse E Social Change. Cambridge: Polity. . 1995. Media Discourse. London: E.Arnold. 
Gibbins, J. \& Reimer B. 1999. The Politics of Postmodernity. London: Sage. Goodrich, P. 1994. Legal Studies entry In The Blackwell's Dictionary of Social Thought. London: Blackwell.

Habermas, J. 1989/1997. The Public Sphere. In Marris P. \& Thornham S. (eds.) Media Studies. A Reader. Edinburgh: Edinburgh UP.

Hall, S. 1985/1996. Signification, Representation, Ideology: Althusser and the Post-structuralist Debate. In: Curran J. et al. (eds.) Cultural Studies and Communications. London: E. Arnold. . 1997. Representation. Cultural Representations and Signifying Practices Sage, London \& OU Press.

HeLD, D. 1993. Models of Democracy. Cambridge: Polity. Jørgensen, W. M. 2002. The Cogito and the Unthought. Foucault's Doubles in Social Scientific Discourse. In: Wodak R. \& Weiss G. (eds.) Theory and Interdisciplinarity. London: Palgrave Macmillan.

Laclau, E. 1996. Universalism, Particularism and the Question of Identity. In: Laclau E. Emancipations. London: Verso.

Latour, B. 1996. On Interobjectivity. In: Mind, Culture and Activity, 3. 4 .

Livingstone S. \& Lunt P. 1994. Talk on Television. London: Routledge. Madsen, L. H. \& Andersen, J. E. 1998. Publikum til Pynt? In: Poulsen I. \& Søndergaard H. (eds.) Mediebilleder - Studier $i$ Mediernes Udtryksformer. Borgen/Media.

Phillips, L. 1999. Media Discourse and the Danish Monarchy: Reconciling Egalitarianism and Royalism. In: Media, Culture E Society, 21: 221-45.

Poster, M. 1990. The Mode of Information. Poststructuralism and Social Context., Cambridge: Polity.

Rose, N. 1999. Powers of Freedom. Reframing Political Thought. Cambridge: Cambridge UP.

Scannel, P. 1989. Broadcast Talk. London: Sage.

Silverstone, R. 1999. Why Study the Media. London: Routledge.

Thompson, J. 1990. Ideology and Modern Culture. Cambridge: Polity. . 1995. The Media and Modernity. Cambridge: Polity.

WodAK, R. \& Wetter E. 1997. Competing Professions in Times of Change: The Discursive Construction of Professional Identities in TV TalkShows Research Report, Department of Linguistics and Department of Sociology, University of Vienna. 